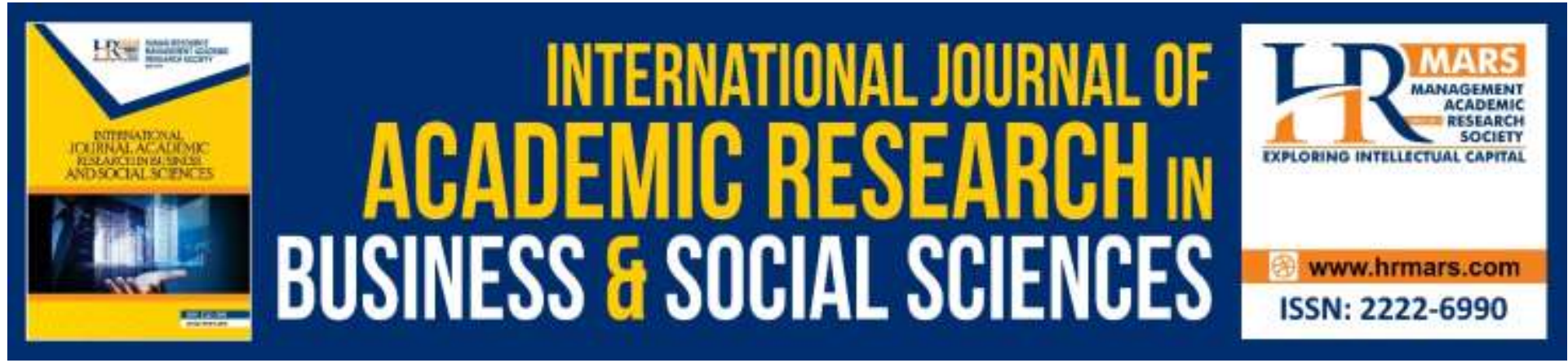

\title{
Preliminary Study on the Implementation of National Human Development Coaching in Malaysian Skills Diploma
}

\author{
Amir Hasan Dawi, Izazol Idris, Regina Lambin, Abu Bakar Ibrahim
}

To Link this Article: http://dx.doi.org/10.6007/IJARBSS/v9-i9/6373

DOI: $10.6007 /$ IJARBSS/v9-i9/6373

Received: 10 August 2019, Revised: 30 August 2019, Accepted: 01 September 2019

Published Online: 25 September 2019

In-Text Citation: (Dawi, Idris, Lambin, \& Ibrahim, 2019)

To Cite this Article: Dawi, A. H., Idris, I., Lambin, R., \& Ibrahim, A. B. (2019). Preliminary Study on the Implementation of National Human Development Coaching in Malaysian Skills Diploma. International Journal of Academic Research in Business and Social Sciences, 9(9), 798-810.

Copyright: (C) 2019 The Author(s)

Published by Human Resource Management Academic Research Society (www.hrmars.com)

This article is published under the Creative Commons Attribution (CC BY 4.0) license. Anyone may reproduce, distribute, translate and create derivative works of this article (for both commercial and non-commercial purposes), subject to full attribution to the original publication and authors. The full terms of this license may be seen at: http://creativecommons.org/licences/by/4.0/legalcode

Vol. 9, No. 9, 2019, Pg. 798 - 810

http://hrmars.com/index.php/pages/detail/IJARBSS

JOURNAL HOMEPAGE

Full Terms \& Conditions of access and use can be found at http://hrmars.com/index.php/pages/detail/publication-ethics 


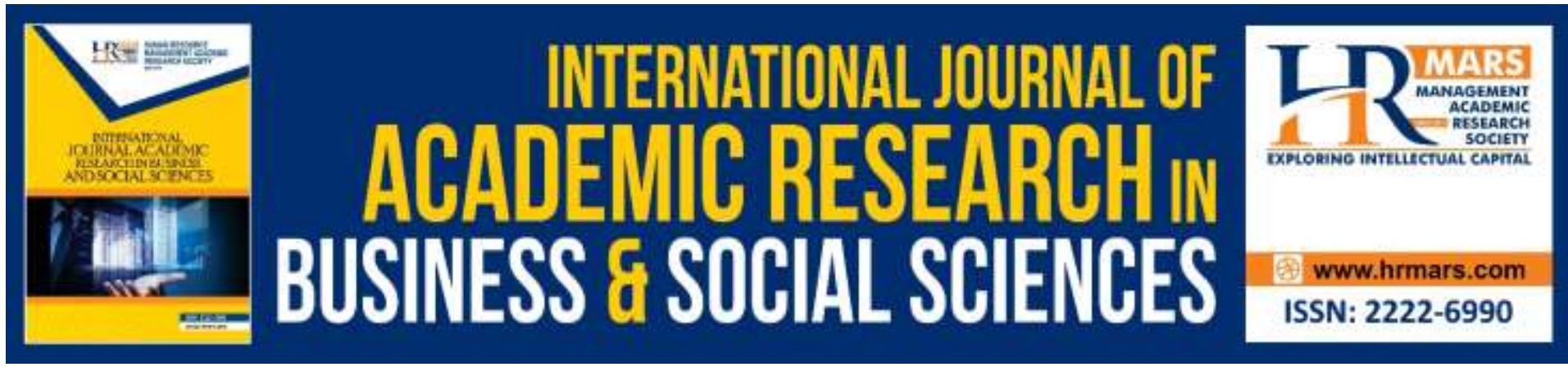

\title{
Preliminary Study on the Implementation of National Human Development Coaching in Malaysian Skills Diploma
}

\author{
Amir Hasan Dawi, Izazol Idris, Regina Lambin \\ Faculty of Human Development, Sultan Idris Education University, 35900 \\ Tanjung Malim, Malaysia. \\ Abu Bakar Ibrahim \\ Faculty of Art, Computing, and Creative Industry, Sultan Idris Education \\ University, 35900 Tanjung Malim, Malaysia.
}

\begin{abstract}
Employability and unemployment continue to be urgent issues that graduates faced daily in 21st Century employment market. Graduates from various local or overseas Institutions of Higher Education face increased competition for limited employment opportunities. Technical or academic qualification is no longer the only requirement needed to secure employment. Graduates require to have value-added to compete in the job market. Nowadays, human social skills turn out to become one of the vital prerequisite and an essential requirement needed by the industry. Hence, coaching is seen as a crucial valueadded to enhance graduate employability. This study was designed to determine the potential of the Diploma in National Human Development Coaching to be implemented as a value-added program for graduates. In collecting qualitative data, the study was conducted through document analysis and interview involving five trained coaches at selected sites in Sabah and Sarawak. In-depth interviews were conducted to get their views on the appropriateness of Competency Unit, Competency Profile Component in National Occupational Skill Standard that is assessed based on their experiences. The interviews were audio-taped, verbatim transcribed, analyzed, and imported into Atlas.ti software for data processing. The findings indicated the potential for the implementation of this program for graduates as an added value in enhancing their skills for employment market of the $21^{\text {st }}$ century.
\end{abstract}

Keywords: Graduate Employability, Malaysian Skills Diploma, Human Development Coaching, Socialization, Nationhood

\section{Introduction}

Graduate marketability is a growing issue. Official statistics released show a 0.3 per cent increase in the unemployment rate from year to year (Department of Statistics Malaysia, 
2016), which is mostly contributed by the Higher Education Institute (HEI) graduates. The Harian (2016) summarized that 34 out of 100 university graduates were unemployed graduates. In fact, since 2012, the Department of Statistics has stated that 76,200 graduates are unemployed due to a lack of job skills (Utusan Malaysia, 2012). A growing number of graduates from various local or overseas HEls have increased competition for fewer job opportunities.

What is more, is that the areas of specialization offered by HEls do not differ much from each other. Among the factors that employers have identified as contributors to graduating job opportunities are English proficiency, attitude and personality, pay scale, skills mismatches, job selection, problem solving and lack of knowledge (The National Graduate Employability Blueprint 2012-2017). Another factor leading to this unemployment is due to poor human social skills. Human development skills such as interpersonal skills, problemsolving, self-esteem, leadership and others are found to be unsatisfactory and do not meet job market standards (JPK, 2017). Therefore, the National Human Development Coaching is created to meet the demands of the current market by integrating the elements of human social skills.

Coaching was seen as an area that can add value to the graduates' skills as it was essential to enhance the employability of graduates. Coaching is essential for future graduates to be provided with an additional value apart from their technical or academic qualification. The other skills will create more job opportunities for them. The Ministry of Human Resources (MHR) has introduced the National Occupational Skills Standard (NOSS) for National Human Development Coaching (NHDC). NHDC is at Level 4 of the Malaysian Skills Certification System, which is equivalence to a diploma level. In this level, the graduate is expected to be "proficient in a wide range of technical and professional work activities within the scope and context. Has a high degree of responsibility and autonomy, as well as being responsible for the work of others and the distribution of resources" (Manusia, 2017). The introduction of the NHDC is also in line with the economic transformation program to double enrollment TVET by 2025 in order to produce intellectual, ethical, high-quality and trained skilled human capital. Therefore, this study is essential to ensure that the implementations of NHDC program can help the candidate improve their skills upon graduation. Specifically, the objectives of this study are to;

i. Identify the suitability of Competency Unit in the National Human Development Coaching program

ii. Identify the potential to implement the National Human Development Coaching program as added value for graduate employability

\section{Literature Review}

Currently, most of the programs that students were attended in the university are focused on academics. The students were surrounded by theoretical lectures, texts and assignments which supplemented by additional requirements in their respective fields of study, e.g. labs, internships, industry training or practicum. Some argue that the academic activities of the universities are very different from the requirements of employment. If in the university the students can excel academically by studying alone, but in the field of work is not so. An employee not only needs expertise in the specialization field; they also have to deal with 
people who need a variety of social skills. Even social skills need to be demonstrated in the searching job process. These skills are one of the significant factors of ones' career success because social skills allow us to interact with each other with expectedness so that we can more readily understand each other and be understood (Beheshtifar \& Norozy, 2013).

After struggling to pursue academic excellence in the classroom, someone could potentially suffer anomie due to social shortfall. Therefore, a student needs to socialize in real human and job environments. There is a various definition of socialization; different sociologists have defined socialization in different ways (Parsons, Bales \& Family, 1955; Grusec \& Hastings, 2015). In this research, socialization is an adaptation of the process to the working environment when a person is dealing with all types of people whereby social skills are highly needed. NHDC is a platform for prospective candidates to gain multiple elements of social skills. The candidate with academic excellence will have more opportunity in the job market because of the social skills that they earn through NHDC.

\section{Coaching}

According to Audet and Cauteret (2013, p.2), coaching is individual support that targets entrepreneur of a new start-up or a growth company aiming to meet a particular need of acquisition, development and skill's improvement. Coaching also defined as a complete entrepreneurial support practice that contains advice, training and learning (Salem \& Lakhal, 2018; Wu, 2016; and Devine et al., 2013). In this study, coaching refer to an individual or group of individuals that conducting courses, delivering lectures, drafting, designing exercises, providing materials, and filling in the form of information sharing. Among the roles played by coaches are in developing modules, planning, managing, and monitoring the implementation of courses and equipment used and training participants in the field. The skills gained through this DNHDC program are expected to make one with a wide range of social skills in multitasking.

\section{Job Prospects}

Job opportunities in this coaching field are widely diversified by various industries such as government agencies and the private sector. These are because the competence of a coach closely associated with this service is used to enhance the level of quality, ability and mental, physical, and personal awareness of every organization involved. The related occupations in this field are; (i) lecturer, (ii) facilitator, (iii) administrator, (iv) manager, (v) consultant, and (vi) entrepreneur. Whereas, the other industry sectors that related to this occupation are education sector, defense sector, administration sector, tourism sector, manufacturing sector, and the service sector.

\section{National Human Development Coaching}

The Diploma in National Human Development Coaching (DNHDC) is a new area of expertise in the NOSS. According to Zain (2016), NOSS is a document that outlines the competencies that should be possessed by skilled workers in Malaysia for a specific field and level of occupation. The development of the NOSS aims to standardize the ability of the coach to have the same set of skills. Initiatives to develop vigorous work standards and curricula are meeting current needs where demand for skilled workers in industry and government agencies is high. Therefore, the development of NOSS for coaching is necessary and will complement each profession through the standards and curriculum established by industry experts in this field. 
The development standard of skills for coaching and training meets job demands in the public and private sectors.

DNHDC was introduced and implemented in 2017 by the Ministry of Human Resource Development, Malaysia. In the early stages of implementation, the DNHDC had been introduced to the experienced coaches who do not have certified or recognition, although they have the skills. It includes those who serve in the military, police, national service training, civil defense and others. They have the opportunity to obtain a certificate through the Recognition of Prior Achievement (RPA) method. In this method, the assessment was based on the documented portfolio of experience and the Report of Prior Skills Performance (RPSP). The method of certification only can be applied to individuals who have at least five years of experience as a coach.

The DNHDC aims to produce skilled, knowledgeable and highly skilled workers in the field of training and coaching for the industrial and educational sectors (JPK, 2017). Thus, the content of the curriculum that formulated intended to produce skilled human capital. Coaching job market opportunities cover a wide range of public and private agencies as their competencies as coaches closely linked to quality improvement, mental improvement, physical and personality capabilities in any related organization. DNHDC's Competency Profile Components (CPC) includes seven-unit of competency. Each Competency Unit (CU) has a variety of work activities described in the NOSS for NHDC. The seven core CUs are namely, (i) Implementation of physical training, (ii) Implementation of training methodology, (iii) Implementation of nationhood training, (iv) Implementation of community service training, (v) Self-development, (vi) Monitoring of safety, health and environment training, and (vii) Coaching administration.

\section{Implementation of Physical Training}

The implementation of physical training is a training activity that involves the whole body in increasing muscle endurance, increasing the level of body fitness as well as endurance cardiovascular. Physical training can be carried out at the various indoor or outdoor location of training. Individuals who are skilled in this CU can perform train and coach the marching exercises, high ropes training, obstacle training, water exercises, physical exercises, basic martial arts, field exercises as well as aerobic exercise. The $\mathrm{CU}$ is also to ensure an increased level of discipline, building excel character, increased self-motivation, fostering a spirit of teamwork as well as increase safety awareness.

\section{Implementation of Training Methodology}

The implementation of the training methodology is a process of learning skills regarding the method or system that including methods, techniques and principles used in an activity of discipline as in training as well as teaching and learning. In this context, training was focusing on a process created to enhance the skills of the individual to facilitate the individual to perform the assigned tasks. Those who have skill in this CU are capable of conducting a lecture, outdoor training, in-group activities, online training, and case study or project. The outcome of this $\mathrm{CU}$ is to ensure that individuals who receive training will master the knowledge of impactful and systematic training methodologies to pass on to the participants by meeting the training criteria set by the organization's training procedures. The mastery of various delivery methods and techniques with the use of teaching aids will enhance the skills, interests and understanding of the participants. 


\section{Implementation of Nationhood Training}

Implementation of nation-building or kenegaraan training describes the process of delivering content and citizenship training activities as a reference to the parties concerned with nationhood training. Individuals who are skilled in this $\mathrm{CU}$ will have the ability to conduct various forms of nation-building training such as citizenship, conduct group training on concepts of nationality, country, people, government, sovereignty and national unity. The purpose of the $\mathrm{CU}$ is also to ensure that the coaches involved will deliver the content of their training comprehensively, and produce dedicated personnel.

\section{Implementation of Community Service Training}

Community service training is an administrative training course related to the preparation, implementation, monitoring of community service activities. This training aims to optimize the skills of the coach in the approach of providing high impact and positive activities to the target group. Individuals skilled in this $\mathrm{CU}$ are capable of providing community service training needs, activity planning, performing community service activities and preparing activity reports. The result of this $\mathrm{CU}$ is to ensure that individuals are better able to provide, deliver and handle community service activities more efficiently and effectively. These skills also allow coaches to maximize the cost-effective use of resources according to program requirements.

\section{Self-Development}

Self-development is a process of training and equipping coaches with the knowledge and skills that build a more dynamic, skilled and high-performing personality. Individuals who skilled in this CU are capable of planning the training activities, preparing training needs, provide training needs, forming mentor-mentee, forming the self-identity of the individual, and form the nation's identity as prescribed. The result of this $\mathrm{CU}$ is to ensure that coaches are positive, ready to face challenges, capable of solving problems in a variety of situations, and openminded.

\section{Monitoring of Safety, Health and Environment Training}

Safety, Health and Environment Training is a process of training and equipping trainers with knowledge and skills related to the care and supervision of safety, health and environment elements throughout an exercise that involves individuals, equipment, training needs and training areas. Individuals who skilled in this competency unit can identify classified documents, review training equipment conditions, check emergency equipment conditions, check safety or health of trainer and participants, check facility and inspect training site safety under Occupational Safety \& Health Act (OSHA, 1994). The purpose of this CU is to ensure that coaches can be prepared in matters of safety and health training conducted by the instructions issued by the management.

\section{Coaching Administration}

Coaching administration refers to the administrative functions that must be present in the training of the individual who plays the role of coach. The effective of the training will impact the performance and success of the organization. It should follow the training cycle that begins with the analysis of training needs, designing training, implementing and evaluating 
training programs. Individuals skilled in this competency unit will be able to coordinate training documentation, training inventory, human resources, training locations, food and transport needs. The result of this $\mathrm{CU}$ is to ensure that individuals were well trained in the management of training activities, competent in managing training and producing competent individuals in the governance of a training.

\section{Implementation}

The implementation of DNHDC could be in two ways, either through Recognition of Prior Achievement or through a training program at an accreditation center. Recognition of Prior Achievement is for those who have at least five years experienced in coaching. For those who inexperienced, the opportunity to get the DNHDC is through a training program at an accredited center. However, at this time, the DNHDC program was only implemented through Recognition of Prior Achievement. This study aims to see the potential of DNHDC training extended to prospective graduates. Several issues need to be considered before the DNHDC implemented for university students. One of the most important is that the contents and methods of DNHDC. As mentioned, DNHDC was started in 2017. The views of those who have gone through the DNHDC will be examined before further implementation at the accreditation center for the prospective graduates.

\section{Conceptual Framework}

The design of a preliminary conceptual framework (Figure 1) was formed based on the seven core of CUs in CPC of the DNHDC, namely, (i) implementation of physical training, (ii) implementation of training methodology, (iii) implementation of nationhood training, (iv) implementation of community service training, ( $v$ ) self-development, (vi) monitoring of safety, health and environment training, and (vii) coaching administration in order to see the potential of DNHDC training being extended to prospective graduates. Each of these CUs has a variety of work activities described in the NOSS of DNHDC. 


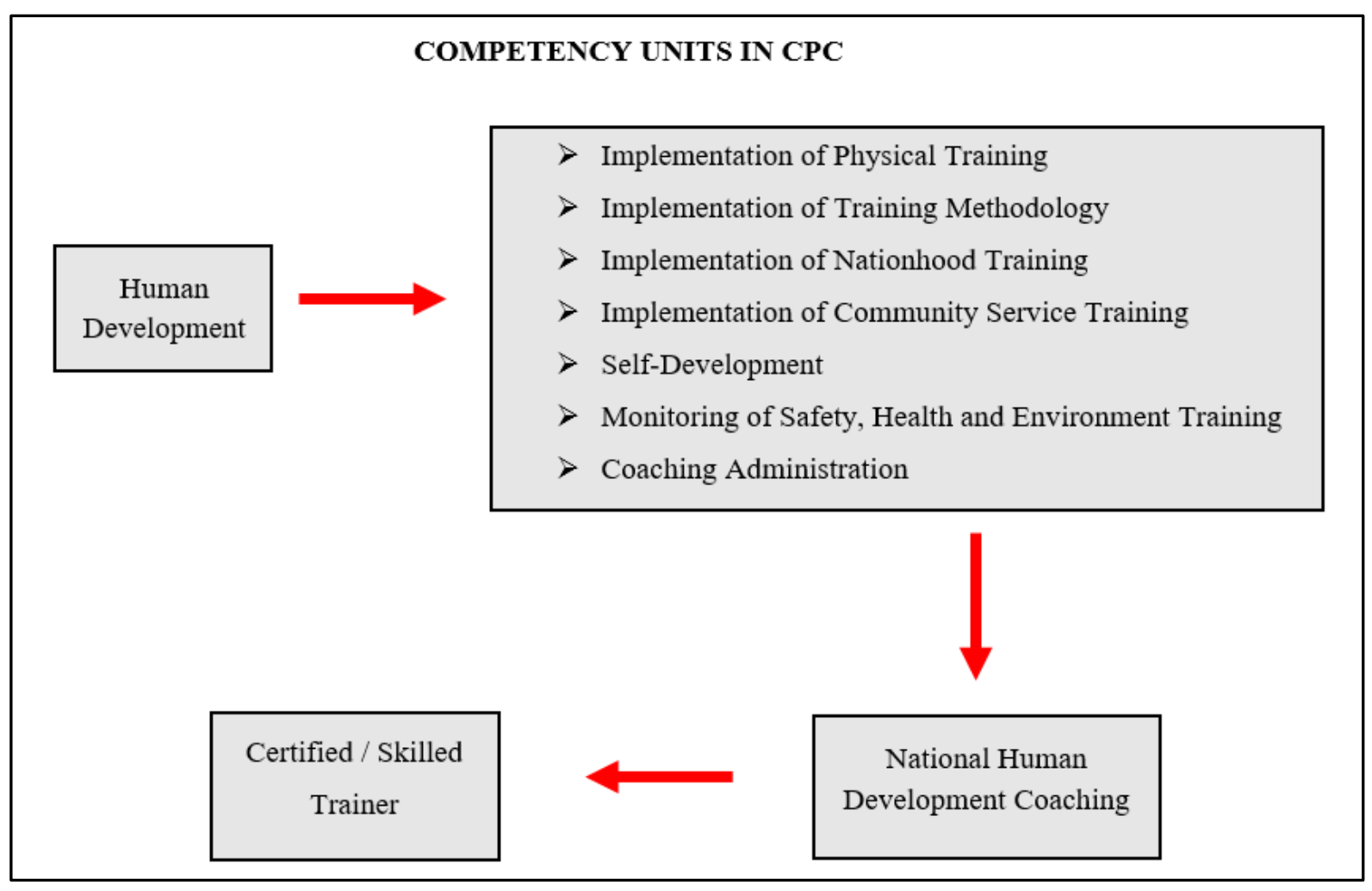

Figure 1: Conceptual Framework

\section{Methodology}

A qualitative approach was employed in this preliminary study by employing data collected through in-depth interviews and document analysis. This study was carried out among five trained coachers in the state of Sabah and Sarawak. The selection of the respondents was made prior to the purposive sampling. This study implemented through interview and questionnaires that involve the respondent of skilled trainers, graduates and related holders. By the end of 2018, it is estimated that over 500 people will end up DNHDC on recognition of prior achievement. Respondents selected from this population to be interviewed and distributed questionnaire. The main purpose is to get their views on the suitability of the DNHDC's component of the skills that are evaluated based on their experience. In addition, the questionnaire is also distributed to the prospective graduates and the stakeholders on the suitability of DNHDC's CU and its delivery method.

The study involved a semi-structured interview, where the interview was conducted based on the prepared protocol. While, the protocols interview were developed through an intensive review of literature guided by the posted research question (Norwaliza \& Ramlee, 2015). The interview protocol is the prime source of case study data. The researcher will interview a wide range of respondents which serves two purposes. The first is to add a greater depth of understanding to issues related to the case and the second purpose is to use the interview to identify key informants who are part of the case (Anderson, 2000).

Besides, the document analysis method was also used to analyze the data in this study. The researcher thoroughly analyzed the documents generated by the organizations that were enclosed in websites, journals, and books. The available and suitable literature was employed in the event of the interview queries that were used to collect the data in this study. The data 
collected were processed using Atlas-ti software to ease the organization and composition of the process of coding and classification and also the development of the link between the components. The recorded audio verbatim transcribed, and the Malay transcripts were double-checked for precision with the records before the interpretation of the data. Documents were thematically analyzed (Boyatzis, 1998; Bryman, 2012; Löfmarck \& Lidskog, 2017) and imported into Atlas.ti software for data processing. After the components were analyzed, they were brought along and interpreted in relevance to the purpose of the study.

\section{Results and Discussions}

To address the research questions, the research data collected from two primary sources, namely, (i) interview and (ii) document analysis. A total of five respondents aged 30 and older, were interviewed in this preliminary study. The five respondents were three females and one male, which is known to be knowledgeable in the coaching program as well as trained coachers. To maintain the confidentiality of the respondents, they were not identified by the name in the findings; instead, they were assigned based on the terms of pseudonyms (Bloomberg \& Volpe, 2008), i.e. RF1, RM5, etc. The research findings obtained from in-depth interviews of all the respondents in this study as well as from document analysis.

Figure 2 shows that the seven core Competency Units of Competency Profile Components contributed to the implementation of DNHDC. The results of this study found that the respondents had the same thoughts about the implementation of DNHDC in for future graduates. The trained coaches believed that the implementation of seven components $\mathrm{CU}$ in NOSS could be used as a guideline in producing skilled and talented graduates with value-added before graduation.

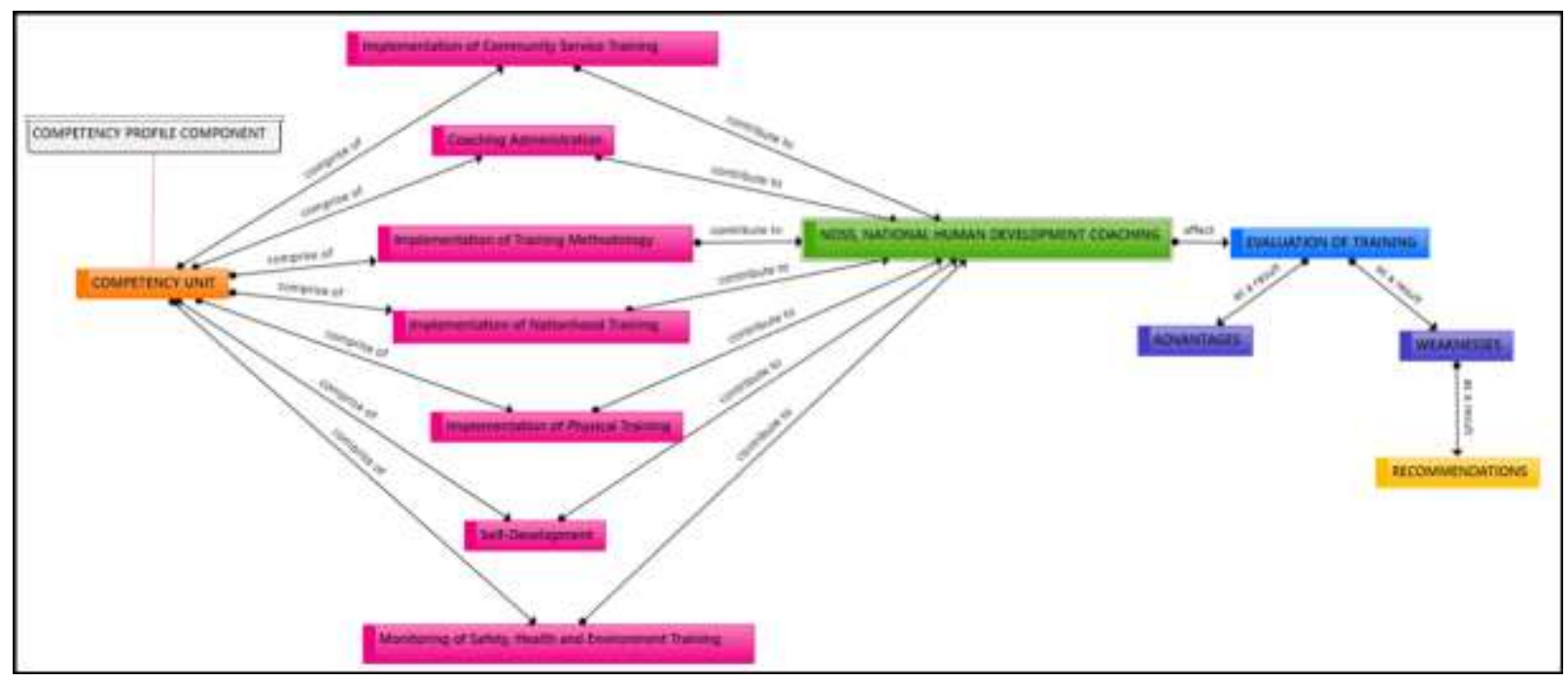

Figure 2: Theme Map of Seven Component Units of Competency Profile Components in NOSS

Based on the interviews, the respondents emphasized that the implementation of DNHDC beneficial for the candidate. The informants stated that the seven components in CU 
were good enough to produce a skilled and talented future coach. Based on the interview that has been conducted, the respondents stated as below;

'...For me it enough 7 CUs...because in its CU has been proven, there was evidence of its own... for examples in its physical module already in CU 1 such as physical is already there, there is evidence that we have participated in that activity so if there. It enough at $7 \mathrm{CU}$ only...' (RF2: $\mathrm{F} / \mathrm{KB} / 1602$ )

'... Yes, for me...7 CUs all there, 7 in 1...Outdoor is there; identity is there, a kind of for statehood it is already there, safety is already there, the sense is there no need to add more enough with the $7 \mathrm{CU}$... ' (RF3: N/KB/1602)

'... for me, it is a tool for us to motivate people because in one CU has many sub-sub headings that focus on more than just physical identity, this CUs is a great title and as we understand the title and the modules involved in each CU ... ' (RM5: H/BS/2601)

Although all the respondents agreed that the implementation of DNHDC in MDS was good enough and beneficial to all of the candidate, yet, it has some weakness that needs to be improved in order to produce skilled coaches in future. RM5 and RF3 stated;

'...It lacks focus on the CU...For the CU; it has been unable to... its implementation program...the delivery of it alone the program itself is not enough but its implementation...' (RM5:H/BS/2601)

'...before we do what we have...at this stage is not much like the other camps, for examples before we have held on one coordinator in one module and know that we see from this session, not all of us are one coordinator for one module that is the examples...l liked the camp in 2014... hold mentor coordinator and for other friends throughout 2014...for example, in 2017... the mentor-mentee program is the only one I have held while I became trainer...so here, we are want to see that mastery at $\mathrm{CU}$ where we can put us at your level...' (RF3: $\mathrm{N} / \mathrm{KB} / 1602$ )

Therefore, it is needed to take serious of the recommendations that have been highlighted by the respondents in this study. The RM5 and RF2 suggested that the implementation of this need to have a proper guideline which can be standardized at all institutions. These are because the program was good enough to be implemented based on the original standard without any alteration. Besides that, the respondents also suggested prolonging the duration of the program to a year instead of five months period. The respondents stated that they need to rush to get the syllabus done due to the hectic schedule. The respondents highlighted the issues as follows;

'...before this, the sole discretion of each camp at their discretion, so the thing is practically non-standard, the implementation here is like here... this is a short cut... this is a detail... the other half is not standard. Although it is good enough to follow 100\% of the same standard, because there are discretionary terms in the job, for example, implementing one module when he said this for training... this class must be done in class... however, when one camp class is 
full...not enough class...so they make it everywhere...so, when you do any program required in the classroom, it should be in the classroom...' (RM5: H/BS/2601)

'... For me, Sir...before it set for five months, it been so rushing to prepare this diploma in 5 months before the year ends... if possible, we want to continue the length of the study to a year. Because of the average, who take this course are mothers who take care of home duties...some go to work, and we cannot do it at our house. We must work at the working hour...if you can extend five months up to one year...' (RF1: F/KB/1602)

\section{Conclusion}

In conclusion, the NOSS curriculum for DNHDC is well-design to develop human capital in coaching as well as to develop social skills. From document analysis, we found that the contents of the seven CU's had fulfilled a variety of topics needed for the program. Based on interviews, respondents agreed that the CU's in DNHDC is enough for producing skills personal as coaches.

As stated in the problem of study, there was an issue of job market opportunities among university graduates. Therefore, this DNHDC is an opportunity for students to increase market adaptability as it can increase the skills that are recognized. The result of the study adapted NOSS DNHDC to training needs from competency aspects and methods to groups without skill, especially university students. In term of suitability as added values for graduates, those who participate in this program will be socialize to various aspect of social skills appropriate to a variety of employment situation. This is because the DNHDC curriculum found to be in line with the current scenario to develop human capital and social skills. Thus DNHDC is a program as added value for graduate employability. The program may help graduate to get job.

Meanwhile, this preliminary study noted some lacking in the implementation through Recognition of Prior Achievement. Among them is about a short period in conducting the program. There is also a suggestion to have a proper guideline for all the training institutions involved. Students may need more time due to their hectic academic schedule and whether students should take DNHDC program during their academic years or after. The way of delivery method for university students still needs to be studied. Hence, further investigation is needed in order to improve.

\section{Acknowledgements}

The first author acknowledges the cooperation of the research participants and thanks, Research Management and Innovation Centre (Research Code: 2018-0228-107-01), Sultan Idris Education University, for the Grant that partially supports this study.

\section{Corresponding Author}

Amir Hasan Dawi, Faculty of Human Development, Sultan Idris Education University, 35900 Tanjung Malim, Malaysia, email: amir.hasan@fpm.upsi.edu.my 


\section{References}

Ahi, B. (2017). The Effect of Talking Drawings on Five-Year-Old Turkish Children's Mental Models of the Water Cycle. International Journal of Environmental and Science Education, 12(3), 349-367.

Anderson, K. A. (2000). Recognition of Being: Reconstructing Native womanhood. Toronto: Second Story Press.

Audet, J. and Cauteret, P. (2013). "Le coaching entrepreneurial: spécificités et facteurs de succès". Journal of Small Business \& Entrepreneurship, Vol.18, pp. 471-489.

Beheshtifar, M., \& Norozy, T. (2013). Social skills: A factor to employees' success. International Journal of Academic Research in Business and social sciences, 3(3), 74.

Behtoui, A., and Neergaard, A. (2016). Social Capital and The Educational Achievement of Young People in Sweden. British Journal of Sociology of Education. Vol. 17. No. 7. 947969.

Salem, B. A., \& Lakhal, L. (2018). Entrepreneurial coaching: how to be modeled and measured? Journal of Management Development, 37(1), 88-100.

Bloomberg, L. D., \& Volpe, M. (2008). Presenting Methodology and Research Approach. Completing Your Qualitative Dissertation: A Roadmap from Beginning to End. 65-93.

Bogardus, E. S. (1922). Introduction to sociology. University of Southern California Press.

Boyatzis, R. E. (1998). Transforming Qualitative Information: Thematic Analysis and Code Development. Sage.

Bryman, A. (2012). Social Research Methods, 4th Ed. Oxford University Press, Oxford.

Collyer, F. M. (2015). Practices of Conformity and Resistance in the Marketisation of the Academy.

Devine, M., Houssemand, C. and Myers, R. (2013). "Instructional coaching for teachers: A strategy to implement new practises in the classroom". Social and Behavioral sciences, Vol. 93, pp. 1126-1130.

Grusec, J. E., \& Hastings, P. D. (Eds.). (2015). Handbook of Socialization: Theory and Research. Guilford Publications.

Jabatan Pembangunan Kemahiran. (2017). Standard Kemahiran Pekerjaan Kebangsaan, Kejurulatihan Bina Insan Negara (National Human Development Coaching).

Jabatan Perangkaan Malaysia, 2016.

Kementerian Sumber Manusia, 2017.

Löfmarck, E., \& Lidskog, R. (2017). Bumping Against the Boundary: IPBES and the Knowledge Divide. Environmental Science \& Policy, 69, 22-28.

Norwaliza, A. W., \& Ramlee, M. (2015). Reflections on Pedagogical and Curriculum Implementation at Orang Asli Schools in Pahang. Procedia - Social and Behavioral Sciences, 172, 442-448.

Occupational Safety and Health Act. (1994). Kuala Lumpur: DOSH Malaysia. p 31

Parsons, T., Bales, R. F., \& Family, S. (1955). Interaction Process. New York, NY:

London.

Sinar Harian, 18 December 2016.

The National Graduate Employability Blueprint 2012-2017. Utusan Malaysia, 9 May 2012.

Wiersma, W., \& Jurs, S. G. (2005). Research Methods in Education. New York NY: John and Willy Son.

Wu, C. F. (2016). "The relationship between business ethics diffusion, Knowledge sharing and service innovation". Management Decision, Vol. 54, N. 6, pp. 1343-1358. 
Zain, R. B. M. (2016). The Development of an Assessment Framework for Vocational Education Training Programs in the NOSS Based Training System (NBTS) and the National Dual Training System (NDTS). Doctoral Dissertation, Universiti Tun Hussein Onn Malaysia. 